\title{
NOTICE TO CONTRIBUTORS
}

Manuscripts of articles and communications should be sent to:

Nadir Özbek, Editor, NPT, Boğaziçi Üniversitesi, Atatürk Enstitüsü, Bebek, Istanbul, 80815 Turkey / e-mail: npt@boun.edu.tr or in North America to:

Reşat Kasaba, Editor, NPT, University of Washington, JSIS Thomson DR-05, Seattle, WA 98195, USA.

NPT publishes manuscripts in English only. The text including foot notes and bibliography, should be double spaced. The first page of the manuscript should contain: (i) the title; (ii) the name(s) and institutional affiliation(s) of the author(s); (iii) an abstract of no more than 100 words.

In-text references should be denoted by parentheses, with commas separating the author, year and-if needed-page number. Multiple references should be separated by a semicolon. This reference format should be used in footnotes as well. Example: (Said, 1979, p. 122, Kağıtçıbaşı, 1986, pp. 490-2).

The full details of the references should be listed only at the end of the text in a separate section entitled REFERENCES. The author(s) should make sure that there is a one-to-one correspondence between the names (years) in the text and those on this list. Sample formats:

BOOK: Said, Edward W. 1979. Orientalism. New York: Vintage Books.

JOURNAL: Kağıtçıbaşı, Çiğdem. 1986. "Status of Women in Turkey: Cross-Cultural Perspectives," International Journal of Middle East Studies, 18(4) November, pp. 485-499.

COLLECTION: Benedict, Peter. 1976. "Aspects of Domestic Cycle in a Turkish Provincial Town," in Peristiany, Jean G. (Ed.), Mediterranean Family Structures. Cambridge: Cambridge University Press, pp. 243260. 
Special Issue: Forty Years of Turkish Migration to Germany

Guest editors: Ayşe Çağlar and Levent Soysal

\section{ARTICLES}

Introduction: Turkish Migration to Germany-Forty Years After

Against Between: A Manifesto

Leslie A. Adelson

Metamorphoses of the "Stranger": Jews in Europe, Polish Peasants in America, Turks in Germany

Nedim Karakayall

Toward a "Minor Literature"? The Case of Ausländerliteratur in Postwar Germany Rita Chin

Turkish Youths in Berlin: Transnational Identification and Double Agency Sabine Mannitz

Ethnicizing the Media: Multicultural Imperatives, Homebound Politics, and Turkish Media Production in Germany

Alevis in Germany and the Politics of Recognition

Martin Sökefeld 133

Alevist Movements at Home and Abroad: Mobilization Spaces and

Disjunction Elise Massicard

Migration From Turkey to Germany: An Ethnic Approach

Ibrahim Sirkeci

The World of Aziza A.: Third Space in Identities

Turkish-German Traffic in Cinema: A Critical Review

Deniz Göktürk 229
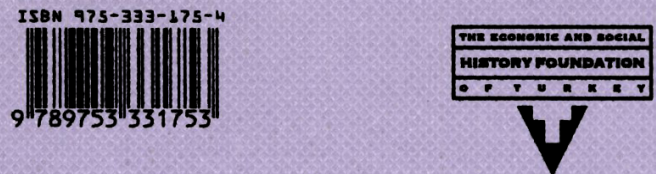